\title{
First occurrence of brachyopid temnospondyls in Southeast Asia and review of the Mesozoic amphibians from Thailand
}

\author{
Thanit Nonsrirach $^{1}$, Sita Manitkoon ${ }^{2}$, and Komsorn Lauprasert ${ }^{1,2}$ \\ ${ }^{1}$ Faculty of Science, Mahasarakham University, Khamrieng, Mahasarakham 44150, Thailand \\ ${ }^{2}$ Palaeontological Research and Education Centre, Mahasarakham University, Kantarawichai, \\ Mahasarakham 44150, Thailand
}

Correspondence: Komsorn Lauprasert (komsorn.1@msu.ac.th)

Received: 21 October 2020 - Revised: 27 January 2021 - Accepted: 27 January 2021 - Published: 12 March 2021

\begin{abstract}
The non-marine Mesozoic sedimentary rocks of Thailand, which consist of the Indochina block and the Sibumasu block, have yielded several terrestrial and aquatic vertebrate fossils, but only few amphibian remains have been reported. Here, we present an overview on the Thai amphibian palaeo-diversity based on the literature, re-examination of published material, new findings, and unpublished material. Thai amphibian fossil remains are assigned to Stereospondyli (Cyclotosauridae, Plagiosauridae, and Brachyopoidea) and Anura and were discovered from four formations, ranging from the Upper Triassic to Lower Cretaceous of Thailand. The occurrence of Brachyopidae in Thailand, which are related to Chinese forms, supports the previous hypothesis of physical connections between the Indochina blocks and the Sibumasu block during the Mesozoic era.
\end{abstract}

\section{Introduction}

The amphibians of the Paleozoic and the Mesozoic can be dived into three major clades: the Seymouriamorpha, the Lepospondyli, and the Temnospondyli (Vitt and Caldwell, 2014). Basal members of temnospondyls were the most diverse and most successful group of amphibians in the Paleozoic, which lived during the Mesozoic Era (Damiani and $\mathrm{Ru}-$ bidge, 2003; Schoch, 2014). Temnospondyls are commonly retrieved in the tetrapod assemblages from Triassic continental deposits such as fluvial and lacustrine environments (Schoch and Milner, 2000; Dias-da-Silva and Dias, 2013).

We present here an update of the amphibian continental fossil record during the Mesozoic in Thailand. The Mesozoic rocks of Thailand consist of two sub-continent blocks. The western part, called "Shan-Thai block" or "Sibumasu block", includes the eastern part of Myanmar and northern, western, and southern parts of Thailand as well as the western peninsula of Malaysia (Fig. 1). The eastern part is the Indochina block, which includes northeastern and eastern parts of Thailand, southern parts of Laos and Cambodia, and the western part of Vietnam (Metcalfe, 1996; Buffetaut and Suteethorn, 1998; Racey, 2009). The Mesozoic rocks in the northeastern part of Thailand, which belong to Indochina, consist of a non-marine red bed sequence deposited in a continental environment (Racey et al., 1996; Racey, 2009). This block consists of seven formations considered Upper Triassic to Cretaceous in age based on invertebrate and vertebrate remains as well as palynomorphs (Meesook et al., 1995; Racey et al., 1996). However, fossils of Thai amphibians (i.e., Cyclotosaurus cf. posthumus, Plagiosauridae, Temnospondyli indet., and Anura) were discovered only from three formations of the Indochina block (Ingavat and Janvier, 1981; Suteethorn et al., 1988; Buffetaut et al., 1994a; Srisuk, 2002, 2005) which are as follows.

1. The Huai Hin Lat Formation is mainly formed by lacustrine bituminous limestone and shales (Buffetaut and Suteethorn, 1998). It is considered Upper Triassic based on palynomorphs, plant macro-remains, conchostracans, and vertebrate remains (Kobayashi, 1975; Racey et al., 1996; Buffetaut and Suteethorn, 1998; Department of Mineral Resources, 2014). The vertebrate assemblages from the Huai Hin Lat Formation consist of actinopterygian fishes (Martin, 1984), lungfish (Martin and Ingavat, 1982), temnospondyls (Ingavat and Janvier, 1981; Suteethorn et al., 1988), and phytosaurs (Buffetaut and Ingavat, 1982). 
2. The Phu Kradung Formation consists of sequences of sandstone, siltstone, and mudstone deposited on a lacustrine-dominated alluvial floodplain environment (Meesook, 2000; Racey, 2009). This formation is assigned to Upper Jurassic based on palynomorphs, bivalves (Racey et al., 1994, 1996; Meesook, 2000), and vertebrate remains which consist of hybodont sharks (Cuny et al., 2005), actinopterygians (Cavin et al., 2003; Cavin and Suteethorn, 2006), temnospondyls (Buffetaut, et al., 1994a), turtles (Tong et al., 2009), crocodiles (Buffetaut and Ingavat, 1980), and dinosaurs (Buffetaut, et al., 2014).

3. The Sao Khua Formation consists of sequences of red clays, sandstones, and conglomerates deposited on a floodplain with a meandering river environment (Buffetaut and Suteethorn, 1998). This formation is assigned to Lower Cretaceous based on palynomorphs, bivalves (Racey et al., 1994, 1996; Meesook, 2000), and vertebrate remains, i.e., hybodont sharks (Cuny et al., 2007), actinopterygian fishes (Cavin et al., 2009), anurans (Srisuk, 2002, 2005), turtles (Tong et al., 2009), crocodilians (Buffetaut and Ingavat, 1980), and dinosaurs (Buffetaut and Suteethorn, 1999).

In the Sibumasu block of the southern peninsula of Thailand, temnospondyls were discovered in the Klong Min Formation (Buffetaut et al., 1994b, c), which is formed by limestone and grey to brown clays, indicating a lacustrine depositional environment (Tong et al., 2002). The Klong Min Formation is considered Middle or Upper Jurassic in age, based on charophytes and vertebrate remains (Buffetaut et al., 1994b; Tong et al., 2002; Girard et al., 2020). The vertebrate assemblages of this formation consist of hybodont sharks, actinopterygian fishes, lungfish, turtles, and crocodiles (Buffetaut et al., 1994b, c; Tong et al., 2002).

Although thousands of vertebrate remains have been found, few amphibian remains have been reported. More recently, new specimens of amphibians (intercentra and a posterior part of a skull) were collected from new Mesozoic localities in Thailand, i.e., Huai Nam Aun locality, Phu Noi locality, and Khao Wong locality (Laojumpon et al., 2014; Chanthasit et al., 2019). In order to understand the diversity and biogeography of Thai Mesozoic amphibians, we describe and re-check the taxonomic status of all amphibian remains housed in the collections of the Sirindhorn Museum (SDM, Kalasin Province) and the Palaeontological Research and Education Centre of Mahasarakham University (PRC, Mahasarakham Province). The relationships between these amphibians and their Asian relatives are used in a palaeobiogeographical framework for a better reconstruction of the physical connections in Southeast Asia.

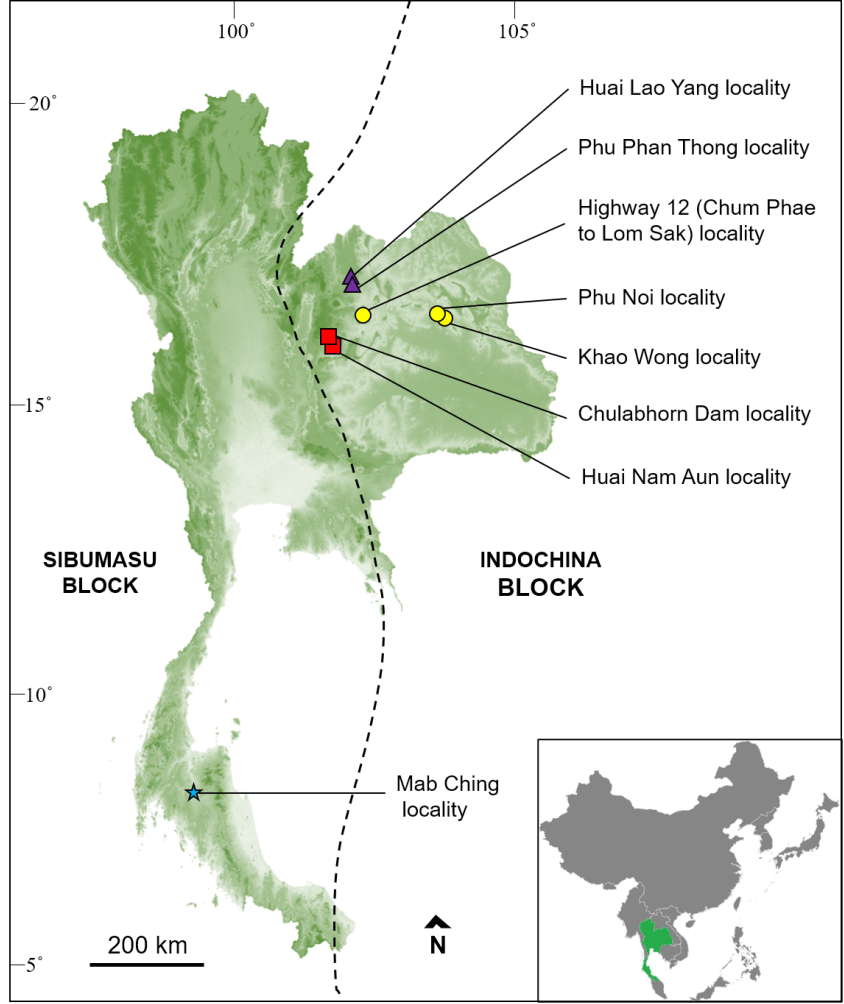

Figure 1. Mesozoic amphibian outcrops from Thailand (symbol); locality in $\square$ Huai Hin Lat Formation (Upper Triassic), $\downarrow$ Khlong Min Formation (Middle or Upper Jurassic), O Phu Kradung Formation (Upper Jurassic), and $\Delta$ Sao Khua Formation (Lower Cretaceous).

\section{Abbreviations}

D.M.R.: Department of Mineral Resources; Ch.D.: Chulabhorn Dam; TF: Thai Fossil; KS: Kalasin; CY-HN: Chaiyaphum - Huai Nam Aun; SHM-PT: Srisuk's House Museum Phu Phan Thong; SHM-HY: Srisuk's House Museum - Huai Lao Yang.

\section{Materials}

The material consists of isolated intercentra, parts of dermal bones, and a posterior part of a skull. It is housed in (1) the Department of Mineral Resources, Cyclotosaurus cf. posthumus (D.M.R. no. Ch.D 001); (2) the Sirindhorn Museum, Plagiosauridae (TF 1453) and Brachyopoidea (KS34-1481, KS34-1474, KS34-1489, and KS37-8); and (3) the Palaeontological Research and Education Centre, Mahasarakham University, Brachyopoidea (TF 3228 and TF 3229), Stereospondyli indet. (CY-HN 364, CY-HN 365, CY-HN 368, CYHN 377, and CY-HN 378) and anuran (SHM-PT 529-530 and SHM-HY 231). 
Table 1. Mesozoic amphibian records from Thailand.

\begin{tabular}{llll}
\hline Formation & Systematic paleontology & Material & Reference \\
\hline $\begin{array}{l}\text { Huai Hin Lat Fm. } \\
\text { (Carnian-Norian) }\end{array}$ & $\begin{array}{l}\text { Cyclotosaurus cf. } \\
\text { posthumus }\end{array}$ & $\begin{array}{l}\text { Posterior part of skull } \\
\text { (D.M.R. no. Ch.D 001) }\end{array}$ & Ingavat and Janvier (1981) \\
\cline { 2 - 4 } & Plagiosauridea indet. & Clavicle (TF 1453) & Suteethorn et al. (1988) \\
\cline { 2 - 4 } & Stereospondyli indet. & Intercentrum (CY-HN 378) & Laojumpon et al. (2014) \\
\cline { 2 - 4 } $\begin{array}{l}\text { Khlong Min Fm. } \\
\text { (Middle-Upper Jurassic) }\end{array}$ & Stereospondyli indet. & $\begin{array}{l}\text { Dermal bone (CY-HN 364, } \\
\text { CY-HN 365, CY-HN 368, CY-HN 377) }\end{array}$ & This paper \\
\hline $\begin{array}{l}\text { Phu Kradung Fm. } \\
\text { (Upper Jurassic) }\end{array}$ & Brachyopoidea indet & Intercentrum (TF 3144) & Buffetaut et al. (1994c) \\
\cline { 2 - 5 } & Brachyopoidea indet & Intercentrum (KS37-8) & Buffetaut et al. (1994a) \\
\cline { 2 - 5 } & Brachyopidae indet. & $\begin{array}{l}\text { Posterior part of skull (KS34-1481) and } \\
\text { intercentra (KS34-1474, KS34-1489) }\end{array}$ & This paper \\
\hline $\begin{array}{l}\text { Sao Khua Fm. } \\
\text { (Lower Cretaceous) }\end{array}$ & $\begin{array}{l}\text { Humeri (SHM-PT 529, SHM-PT 530) } \\
\text { and Pelvic girdle (SHM-HY 231) }\end{array}$ & Srisuk (2002, 2005) \\
\hline
\end{tabular}

\section{Systematic paleontology}

\subsection{Previous published records}

Temnospondyli Zittel, 1888

Stereospondyli Zittel, 1888

Mastodonsauroidea Lydekker, 1885

(sensu Damiani, 2001)

Cyclotosauridae Shishkin, 1964

Cyclotosaurus Fraas, 1889

Cyclotosaurus cf. posthumus

\section{Reference material}

D.M.R. no. Ch.D 001 (Fig. 2a-c); a posterior part of a skull (Ingavat and Janvier, 1981).

\section{Formation/age}

Huai Hin Lat Formation (Carnian-Norian).

\section{Locality and sediment}

The specimen was discovered in 1981 at an outcrop near the Chulabhorn Dam, Khon San District, Chaiyaphum Province. The fossil assemblage layer consists of a grey to red conglomerate.

\section{Description}

D.M.R. no. Ch.D 001 is a posterior part of a comparatively large skull (approximately $20 \mathrm{~cm}$ wide and $11 \mathrm{~cm}$ long), but the lateral part of the right side is missing. However, a pair of otic notches and a pineal foramen are preserved. The pattern of the ornamentation and the shallow interotic embayment of this skull allow an assignment to Cyclotosaurus (Fraas, 1913; Ingavat and Janvier, 1981; Damiani, 2001) and are similar to those of the holotype of Cyclotosaurus posthumus Fraas, 1913 from the Upper Middle Keuper, Bavaria (Germany).

Plagiosauroidea Abel, 1919

Plagiosauridae Abel, 1919

Plagiosauridae indet.

\section{Reference material}

TF 1453 (Fig. 2e-f), a dermal bone (Suteethorn et al., 1988).

\section{Formation/age}

Huai Hin Lat Formation (Carnian-Norian).

\section{Locality and sediment}

Outcrop near the Chulabhorn Dam, Kon San District, Chaiyaphum Province. The outcrop is located in the upper part of the Huai Hin Lat Formation (Suteethorn et al., 1988). The specimen was embedded in a block of carbonaceous black shale rock. 
(a)

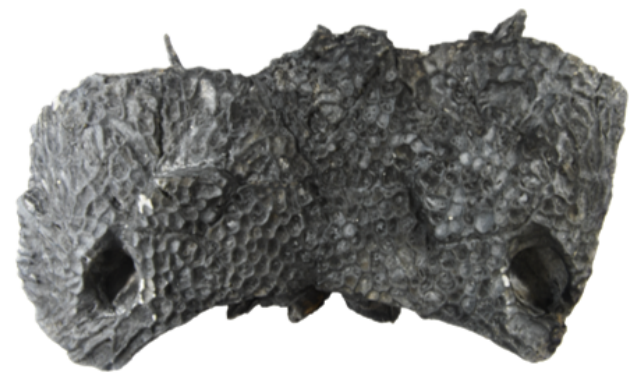

(c)

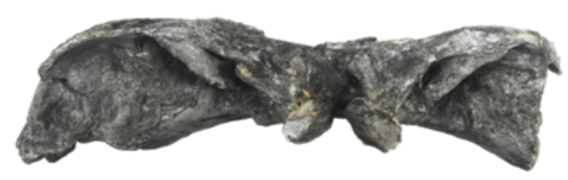

(b)

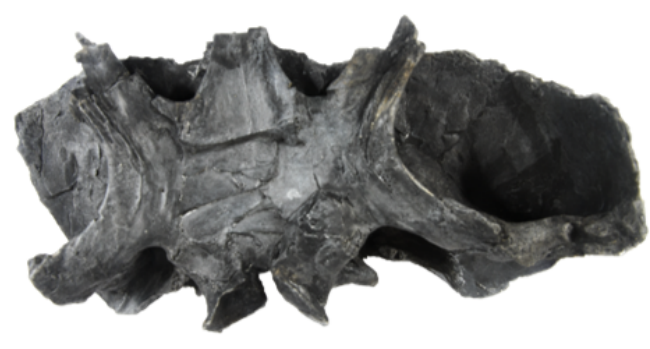

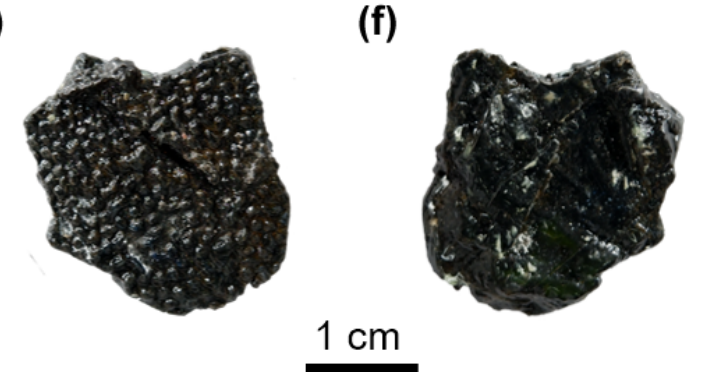

(f)

(e) (d)

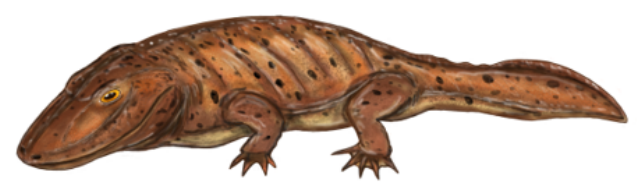

(g)

$2 \mathrm{~cm}$

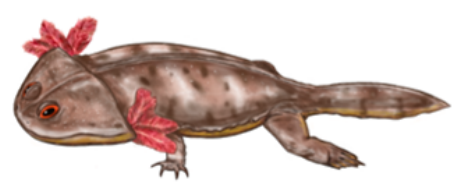

Figure 2. Triassic amphibian remains from Thailand. A replica skull of Cyclotosaurus cf. posthumus (D.M.R. Ch.D 001) in dorsal (a), palatal (b), and posterior views (c). A reconstruction of Thai Cyclotosauridae (d). A dermal bone of Plagiosauroidea indet. (TF 1453) in ventral (e) and dorsal (f) views. A reconstruction of Thai Plagiosauroidea (g). Reconstruction images (d, g) are not to scale (drawn by Sita Manitkoon).

\section{Description}

The specimen TF 1453, approximately $22 \mathrm{~mm}$ wide and $25 \mathrm{~mm}$ long, shows a peculiar ornamentation consisting of tubercles or pustules on its ventral surface. Dorsally, the surface shows some faint radiating grooves and ridges. Based on its ornamentation, TF 1453 was interpreted as a dermal bone fragment of a temnospondyl and was assigned to Plagiosauridae. A comparable ornamentation is observed in Middle to Late Triassic Plagiosauridae, e.g., Gerrothorax pulcherrimus and Plagioscutum ochevi from Europe (Shishkin, 1986; Warren and Snell, 1991; Suteethorn et al., 1988; Jenkins et al., 2008).

\section{Brachyopoidea Lydekker, 1885}

Brachyopoidea indet.

\section{Reference material}

TF 3328 (Fig. 3a-d), TF 3329 (Fig. 3e-h), and TF 3144 (Fig. 3i-1), intercentra (Buffetaut et al., 1994a, c).

\section{Formation/age}

Klong Min Formation (Middle or Upper Jurassic) and Phu Kradung Formation (Upper Jurassic).

\section{Locality and sediment}

TF 3328 and TF 3329 were found in a road cut outcrop near Mab Ching village, Thung Song District, Nakhon Si Thammarat Province, in the southern peninsula of Thailand, which belongs to the Sibumasu block. This outcrop is formed by greyish clays and siltstones, with some freshwater limestone intercalations. It belongs to non-marine Middle or Upper Jurassic rocks based on charophyte algae, palynomorphs, and diatoms (Lei, 1993; Buffetaut et al., 1994c; Girard et al., 2020).

TF 3144 was found in a road cut outcrop at kilometer 68, along Highway 12 from Chum Phae to Lom Sak, in Khon Kaen Province. This area consists of reddish-grey silts and fine-grained reddish sandstone deposited in a meandering river channel (Buffetaut et al., 1994a), which belongs to the Indochina block. 
(a)

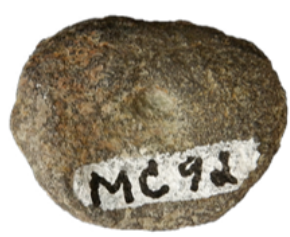

(e)

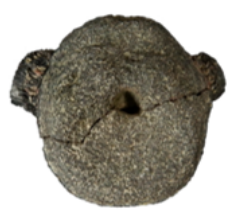

(i)

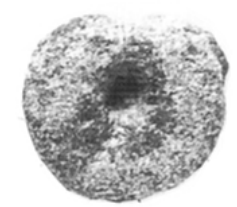

(m)

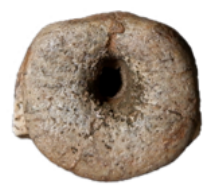

(q)

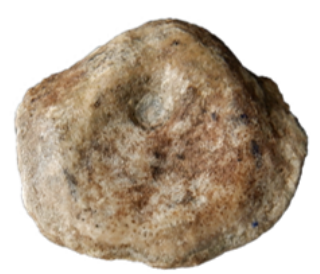

(u)

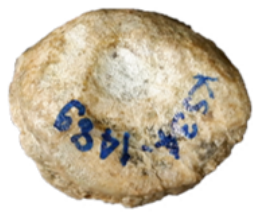

(b)

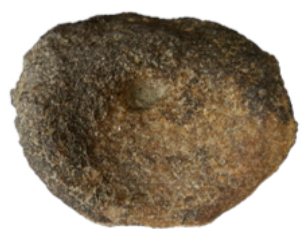

(f)

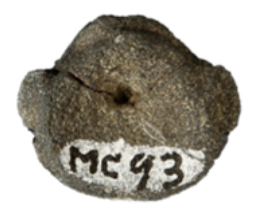

(j)

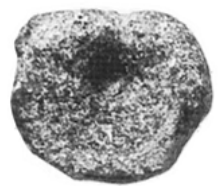

(n)

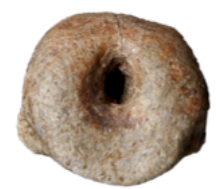

(r)

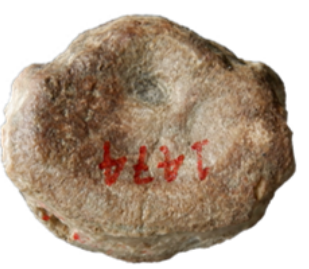

(v)

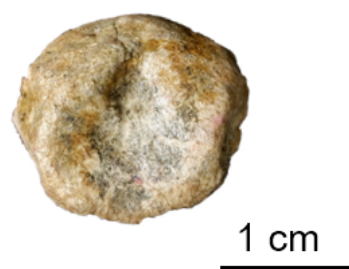

(c)

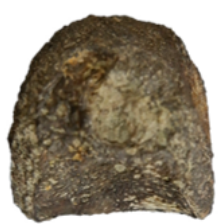

(g)

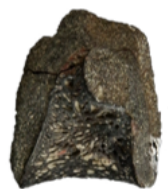

(k)

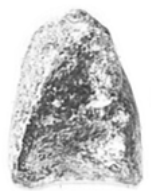

(o)

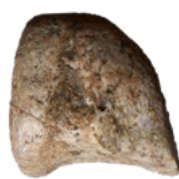

(s)

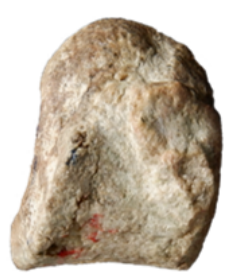

(w)

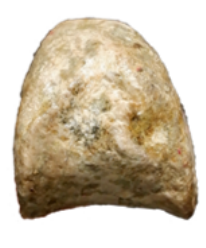

(d)

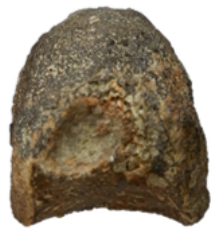

(h)

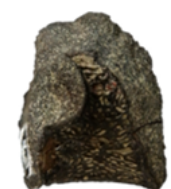

(I)

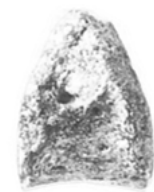

(p)

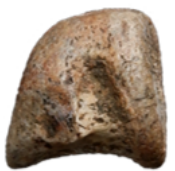

(t)

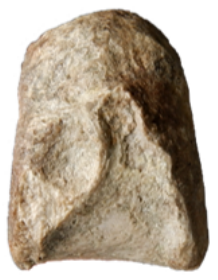

(x)

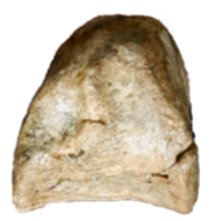

Figure 3. Thai Brachyopoidea indet. intercentra, TF 3228 (a-d), TF 31229 (e-h), TF 3144 (i-l, after Buffetaut et al., 1994b; fig. 1), and KS37-8 (m-p). Thai Brachyopidae indet. intercentra, KS34-1474 (q-t) and KS34-1489 (u-x). Anterior views (a, e, i, m, q, u), posterior views (b, f, j, $\mathbf{n}, \mathbf{r}, \mathbf{v})$, left views (c, $\mathbf{g}, \mathbf{k}, \mathbf{o}, \mathbf{s}, \mathbf{w})$, and right views $(\mathbf{d}, \mathbf{h}, \mathbf{l}, \mathbf{p}, \mathbf{t}, \mathbf{x})$. 


\section{Description}

All specimens are wedge-shaped intercentra. Both anterior and posterior surfaces are concave and show a marked circular notochordal canal, which is visible as a circular pit. The pleurocentra are reduced or absent, which is a typical feature of stereospondyls (Milner et al., 1994; Witzmann and Gassner 2008). The wedge-shaped morphology and the notochordal pit of TF 3328, TF 3329, and TF 3144 is consistent with the intercentrum morphology of the Brachyopoidea (Shishkin, 1991; Warren et al., 1997, 2011; Warren and Dammiani, 1999), which are similar to the intercentra discovered from the Jurassic Indochina block, e.g., Gobiops desertus from the Gobi Desert of Mongolia (Shishkin, 1991).

Anura Fischer von Waldheim, 1813

Anura indet.

\section{Reference material}

SHM-PT 529 (Fig. 4a-b) and SHM-PT 530 (Fig. 4c-d), humeri; SHM-HY 231 (Fig. 4e-f), pelvic girdle (Srisuk, 2002, 2005).

\section{Formation/age}

Sao Khua Formation (Lower Cretaceous).

\section{Locality and sediment}

The humeri (SHM-PT 529 and SHM-PT 530) were collected in a road cut outcrop near Phu Phan Thong village, Muang District, Nong Bua Lamphu Province. These fossils were embedded in a pale olive fine-grained siltstone (Srisuk, 2002).

The pelvic girdle (SHM-HY 231) was discovered in a road cut outcrop near the Huai Lao Yang reservoir road, Nong Bua Lamphu Province. The outcrop is formed by reddish-brown micaceous siltstones and lime-nodule conglomerates (Srisuk, 2005).

\section{Description}

The left (SHM-PT 529) and right humeri (SHM-PT 530) are represented by their distal parts. They are elongated with a slender shaft, slightly curved in lateral view, with rounded capitulum.

The partial pelvic girdle (SHM-HY 231) consists of parts of the ischium, pubis, and acetabulum, while the ilium shaft is not preserved. The acetabular fossa is nearly circular with a posteriorly widened acetabular rim. The base of the ilium shaft has a triangular cross section. These features are reminiscent of an anuran amphibian, but the taxonomic identification of these incomplete specimens is difficult.

\subsection{Unpublished material}

Temnospondyli Zittel, 1888

Stereospondyli Zittel, 1888

Stereospondyli indet.

\section{Reference material}

CY-HN 378 (Fig. 5a-d), intercentrum (Laojumpon et al., 2014); CY-HN 364 (Fig. 5e-f), left clavicle bone; and CYHN 365 (Fig. 5g-h), CY-HN 368 (Fig. 5i-j), and CY-HN 377 (Fig. 5k-1), dermal bones.

\section{Formation/age}

Huai Hin Lat Formation (Carnian-Norian).

\section{Locality and sediment}

These specimens were collected by a Thai-French paleontological team during an excursion in 2010 at Huai Nam Aun, an outcrop situated near the Nong Yakong village, Khon San District, Chaiyaphum Province. This locality contains various beds of limestone and mudstone, deposited in brackish water near a calcium carbonate source (Laojumpon et al., 2014). Other fossils such as Hybodus teeth, bony fish scales, and coprolites have also been found from this locality (Laojumpon et al., 2012, 2014).

\section{Description}

The material consists of an intercentrum and several fragments of dermal bones. A large intercentrum (CY-HN 378, Fig. 5a-d) is preserved over a length of approximately $65 \mathrm{~mm}$ and is $33 \mathrm{~mm}$ thick. CY-HN 378 is a disk-shaped intercentrum with reduced or absent pleurocentra (Laojumpon et al., 2014). The anterior and posterior faces of CY-HN 378 are concave. Laterally, the parapophyses are located in less than half of the total length. These features share characters with Stereospondyli (Milner et al., 1994; Witzmann and Gassner, 2008; Laojumpon et al., 2014). The shape of CYHN 378 is comparable to those of the Metoposauroidea or Mastodonsauroidea intercentrum (Moser and Schoch, 2007; Sulej, 2007; Fortuny et al., 2019; Marzola et al., 2017). The Plagiosauroidea possess cylindrical intercentra (Warren and Snell, 1991; Konietzko-Meier et al., 2014). The Brachyopoidea commonly show a wedge-shaped intercentrum in lateral view (Shishkin, 1991; Warren and Snell, 1991; Warren et al., 1997, 2011; Warren and Dammiani, 1999; Averianov et al., 2008).

The other undescribed specimens are dermal bone fragments. The largest fragment (CY-HN 364, Fig. 5e-f) shows two distinct types of heavy ornamentation in ventral view, i.e., radial and polygonal sculptures. The radial sculpture 
(a)

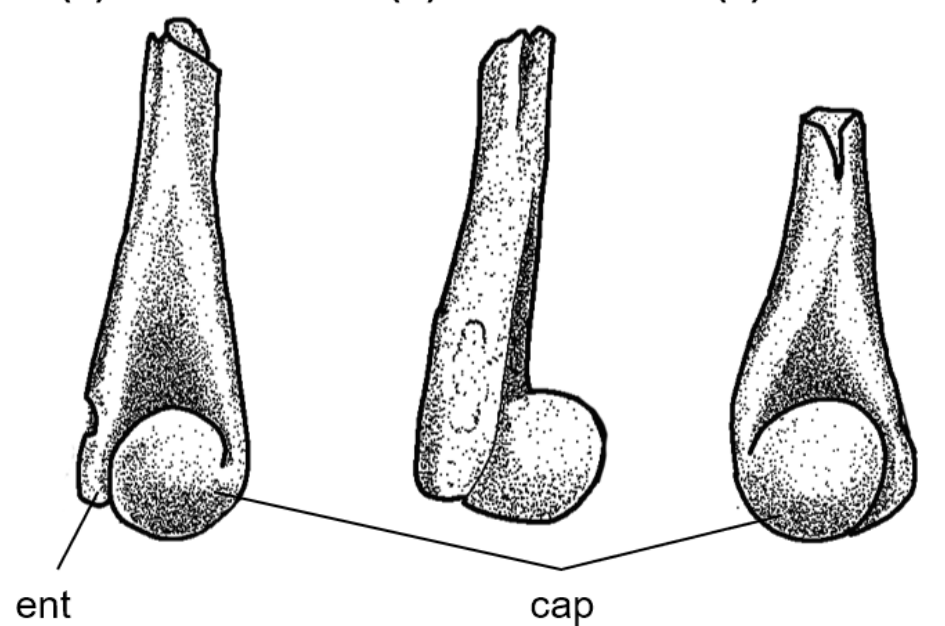

(d)

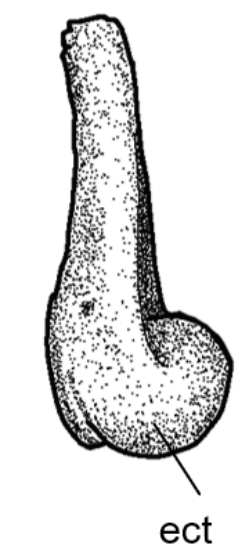

(e)

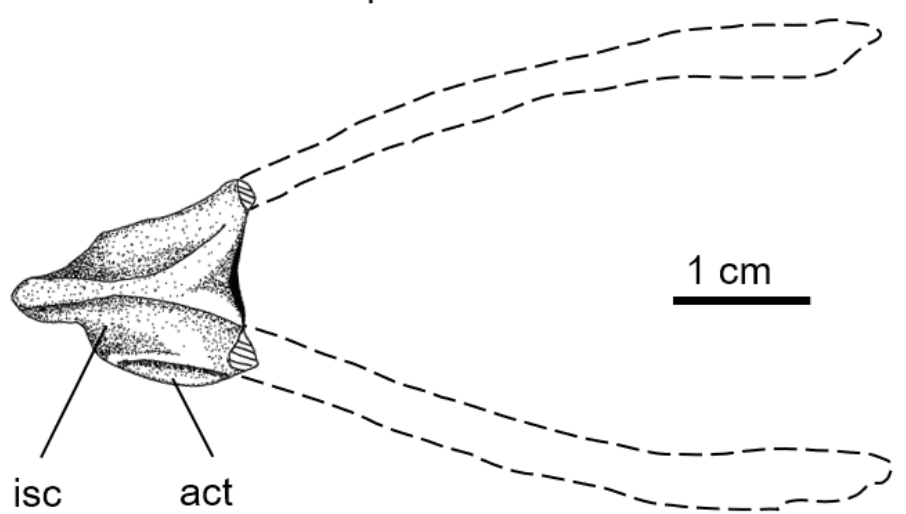

(f)

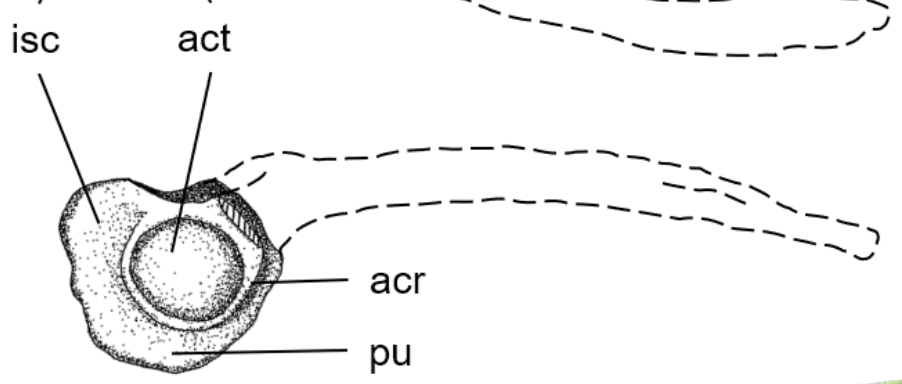

(g)

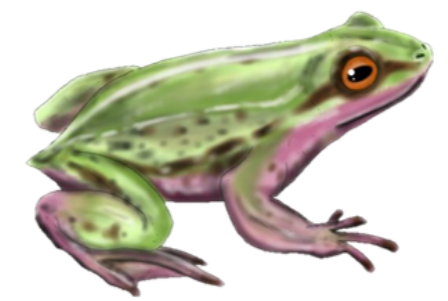

Figure 4. Cretaceous anuran remains from Thailand: left humerus, SHM-PT 529 in ventral (a) and medial view (b); right humerus, SHM-PT 530 in ventral (c) and medial view (d). Partial pelvic girdle, SHM-HY 231 in dorsal (e) and lateral view (f) (after Srisuk, 2002, 2005). Reconstruction of Thai anuran (g) is not to scale (drawn by Sita Manitkoon). Abbreviations: act, acetabulum; acr, acetabulum rim; cap, capitulum; ect, ectepicondyle; ent, entepicondyle; isc, ischium; pu, pubis.

consists of parallel or radial ridges without transverse ridges, while the polygonal sculpture, located close to the lateral edge of the bone, consists of short ridges connected and forming polygons in a honeycomb or hexagonal shape. The dorsal surface is smooth with a part of the ascending process located along the lateral edge. The polygonal ornamen- tation located close to the lateral edge and the presence of an ascending process indicate that CY-HN 364 is a left clavicle bone. The other small dermal fragments, i.e., CY-HN 365 (Fig. 5g-h), CY-HN-368 (Fig. 5i-j), and CY-HN-377 (Fig. $5 \mathrm{k}-\mathrm{l}$ ), are covered by radial and polygonal ornamentation in ventral view. These specimens, however, could be as- 
(a)

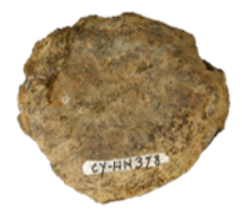

(b)

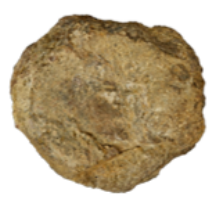

(c)

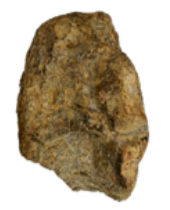

(d)

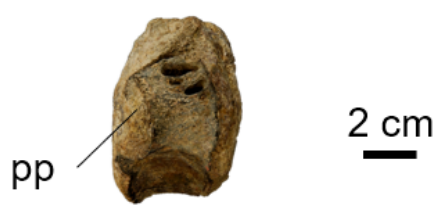

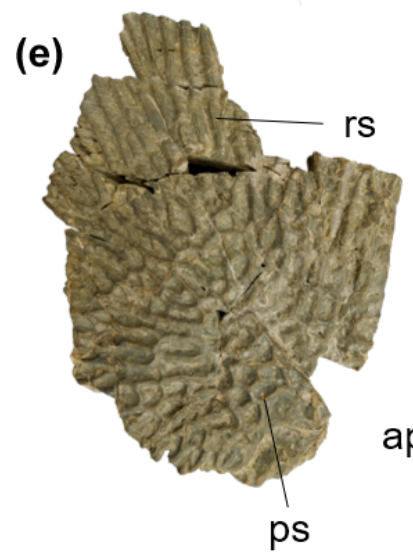

(f)

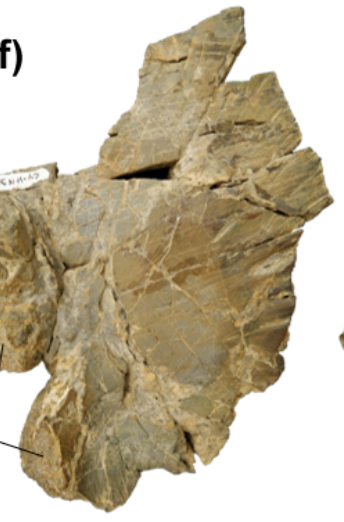

(g)

(h)

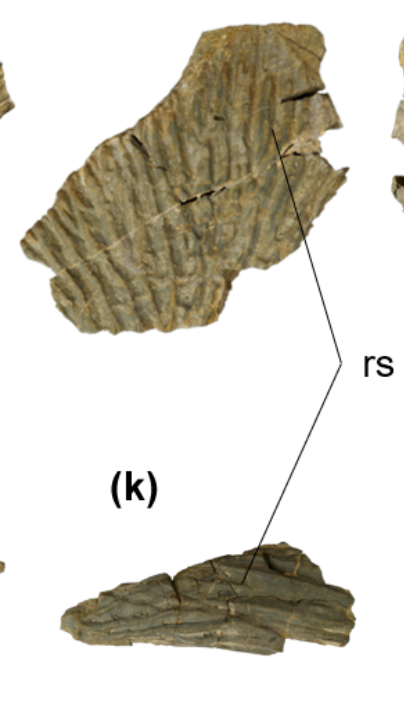

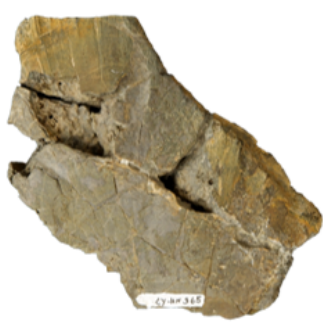

rS

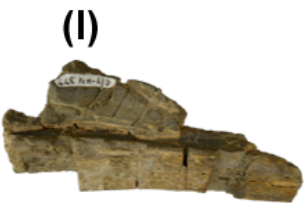

Figure 5. New Triassic amphibian remains from Thailand. An intercentrum of Stereospondyli indet. (CY-HN 378) in anterior (a), posterior (b), left (c), and right (d) views. Dermal bone fragments of Stereospondyli indet. of CY-HN 364 (e-f), CY-HN 365 (g-h), CY-HN368 (i-j), and CY-HN-377 (k-l) in ventral view and dorsal view. Abbreviations: ap, ascending process; pp, parapophyses; ps, polygonal sculpture; rs, radial sculpture.

signed as either interclavicle or clavicle bones. Based on the shape of the intercentrum and ornamentation pattern, these specimens could refer to either the late Triassic Mastodonsauroidea (e.g. Cyclotosaurus) or Metoposauroidea (Chowdhury, 1965; Warren and Snell, 1991; Sulej and Majer, 2005; Sulej, 2007; Brusatte et al., 2015; Antczak and Bodzioch, 2018). Therefore, more evidence is required for a familylevel identification.

Brachyopoidea Lydekker, 1885

Brachyopoidea indet.

\section{Reference material}

KS37-8 (Fig. 3m-p), intercentrum.

\section{Formation/age}

Phu Kradung Formation (Upper Jurassic).

\section{Locality and sediment}

KS37-8 was collected at the Khao Wong locality in Khao Wong District, Kalasin Province. Sediments in this locality are grey to green siltstones.

\section{Description}

KS37-8 is a wedge-shaped intercentrum with the dorsal edge much shorter than the ventral edge. The parapophyses are close to the posterodorsal margin on the lateral surface. Both anterior and posterior surfaces are concave and show a marked circular notochordal canal, which is visible as a circular pit. The pleurocentra are reduced or absent. This intercentrum KS37-8 probably belongs to Brachyopoidea since it is the only Stereospondyli superfamily retrieved beyond the Triassic (Buffetaut et al., 1994b). Furthermore, the wedgeshaped morphology of KS37-8 resembles the intercentra of the Brachyopoidea (Shishkin, 1991; Warren et al., 1997; Warren and Dammiani, 1999; Warren et al., 2011), which are similar to the intercentra discovered from the Indochina block (TF 3144) and Sibumasu blocks (TF 3328 and TF 
3329) of Thailand (Buffetaut et al., 1994a, c). However, the intercentrum is not sufficiently diagnostic for identification at the family level.

\section{Brachyopidae indet.}

\section{Reference material}

KS34-1481, posterior part of a skull (Fig. 6a-b); KS34-1474 (Fig. 3q-t) and KS34-1489 (Fig. 3u-x), intercentrum.

\section{Formation/age}

Phu Kradung Formation (Upper Jurassic).

\section{Locality and sediment}

The specimens were found in an outcrop at the Phu Noi locality, near Ban Dinchi village, Kham Muang District, Kalasin Province. Sediments at this site are grey to green siltstones. Other vertebrate fossils consist of the hybodont shark Acrodus kalasinensis, the ginglymodian fish Isanichthys lertboosi, the lungfish Ferganoceratodus annekempae, the xinjiangchelyid turtles Phunoichelys thirakupti and Kalasinemys prasarttongosothi, the teleosaurid crocodilian Indosinosuchus potamosiamensis, dinosaurs, and pterosaurs (Buffetaut et al., 2014; Cuny et al., 2014; Deesri et al., 2014; Tong et al., 2015, 2019; Martin et al., 2018; Cavin et al., 2020).

\section{Description}

The material consists of three temnospondyl specimens not found in association: the posterior part of the skull (KS341481, Fig. 6a-b) and two intercentra (KS34-1474, Fig. 3q-t and KS34-1489, Fig. 3u-x). The skull (KS34-1481) is short (approximately $14 \mathrm{~cm}$ width and $12 \mathrm{~cm}$ length), lacking otic notch and tabular horn in the supratemporal region. Ventrally, the interpterygoid vacuities are large, and the cultriform process of the parasphenoid is gracile and long. Posteriorly, the occipital condyles are rounded and projected well behind the posterior edge of the skull. This specimen is under study for a more detailed anatomical description. The intercentra (KS34-1474 and KS34-1489) are wedge-shaped with concave posterior surface and slightly convex anterior surface. The anterior surface shows a well-marked deep circular pit. The short skull, which lacks otic notch and tabular horn, and the position of occipital condyles are typical characters of Brachyopidae (Warren and Marsicano, 1998, 2000), similar to those of the Jurassic brachyopid temnospondyl skull from China such as Sinobrachyops placenticephalus (Dong, 1985).

\section{Discussion}

Hitherto, the Upper Triassic Indochina block of Thailand revealed at least two taxa of temnospondyls consisting of $C y$ clotosaurus (Ingavat and Janvier, 1981) and the plagiosaurids
(Suteethorn et al., 1988). Moreover, the newly discovered specimens from the Huai Hin Lat Formation, i.e., dermal bones (CY-HN 364, 365, 368, and 377) and an intercentrum (CY-HN 378), are of uncertain affinities. At first glance, the disk shape and circular periphery of CY-HN 378 resemble Metoposauroidea more than Mastodonsauroidea (Warren and Snell, 1991). However, recent studies indicated that the intercentra of both taxa are very similar in shape (Moser and Schoch, 2007; Sulej, 2007; Marzola et al., 2017; Fortuny et al., 2019). Therefore, it is difficult to assign the Thai intercentrum to a specific taxon. In addition, the dermal sculptures of clavicles (CY-HN 364, CY-HN 365, CYHN 368, and CY-HN 377), consisting of polygonal and radial patterns, are comparable to the ornamentation observed in Metoposauroidea, e.g., Metoposaurus algarvensis, M. maleriensis, and M. krasiejowensis (Chowdhury, 1965; Brusatte et al., 2015; Antczak and Bodzioch, 2018), and Mastodonsauroidea, e.g., Cyclotosaurus intermedius (Sulej and Majer, 2005).

For the aforementioned reasons, the Thai postcranial specimens are possibly related to Metoposauroidea or Mastodonsauroidea. Metoposauroidea are known from the Late Triassic of Africa (Dutuit, 1978; Fortuny et al., 2019), Europe (von Meyer, 1842; Sulej, 2002, 2007; Milner and Schoch, 2004; Brusatte et al., 2015), North America (Case, 1922; Branson and Mehl, 1929; Zeigler et al., 2002; Lucas et al., 2010), and India (Chowdhury, 1965; Sengupta, 2002; Chakravorti and Sengupta, 2019), but they have not been reported in Southeast Asia. Mastodonsauroidea have been reported in Europe (Maryanska and Shishkin, 1996; Schoch, 1999; Fortuny et al., 2011; Sulej and Niedźwiedzki, 2013), Australia (Warren, 1972; Damiani, 1999), North and South America (Schoch, 2000; Eltink et al., 2017; Marzola et al., 2017), Africa (Damiani, 2001; Shishkin et al., 2004; Dahoumane et al., 2016; Peecook et al., 2017), Russia (Novikov and Ilyina, 1995), India (Mukherjee and Sengupta, 1998; Damiani, 2001), Japan (Nakajima and Schoch, 2011), China (Liu and Wang, 2005; Liu, 2016), and Thailand (Ingavat and Janvier, 1981). Dzik and Sulej (2007) noted that Metoposauroidea and Mastodonsauroidea have sometimes been discovered in the same locality, i.e., the Krasiejów clay pit in Poland, suggesting that the discovery of fossils of Metoposauroidea in the Late Triassic rocks of Thailand is possible as well.

From the biological point of view, Buffetaut and Suteethorn (1998) noted that the freshwater vertebrate remains from the Late Triassic Huai Hin Lat Formation are reminiscent of the Norian Stubensandstein Formation from Germany. Both formations have yielded remains of actinopterygian fishes (semionotids), turtles, amphibians (cyclotosaurids), and phytosaurs (Ingavat and Janvier 1981; Buffetaut and Ingavat, 1982; Tong et al., 2003; Milner and Schoch, 2004; Lopez-Arbarello, 2008; Havlik et al., 2013; Laojumpon et al., 2014), suggesting a biogeographical link between the Indochina block, and Laurussia. This conclusion agrees with the hypothesis of a large physical 
(a)

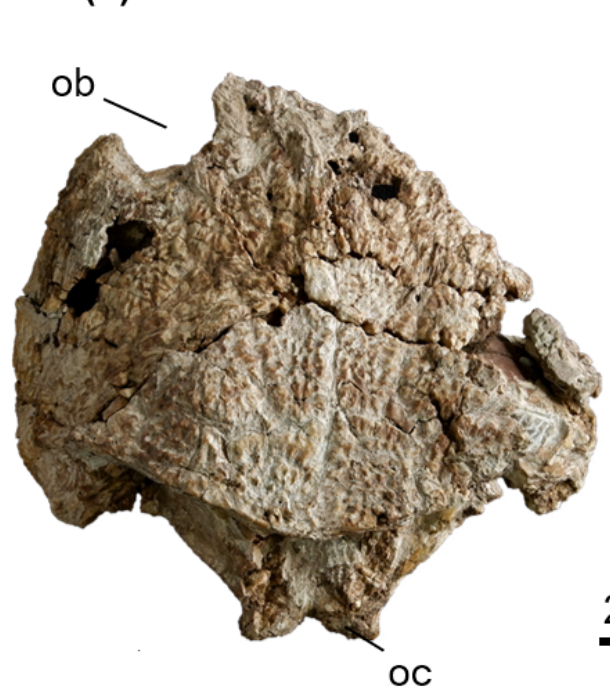

(c)

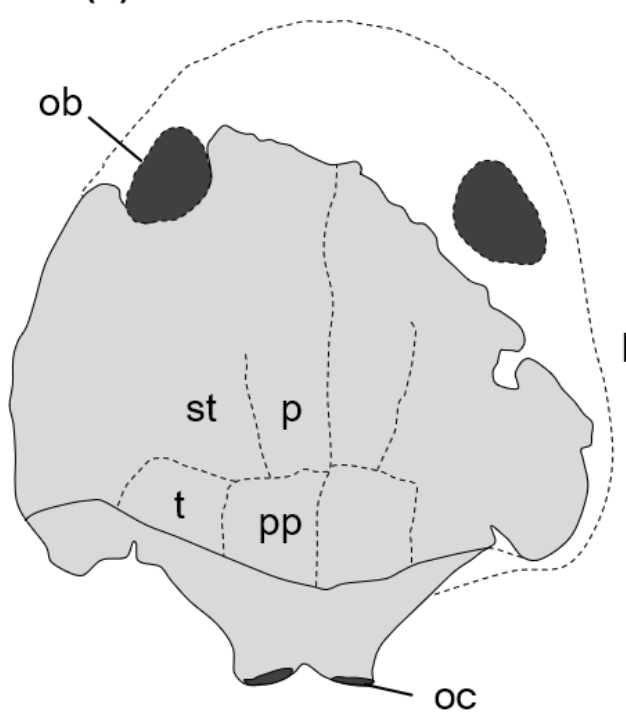

(b)

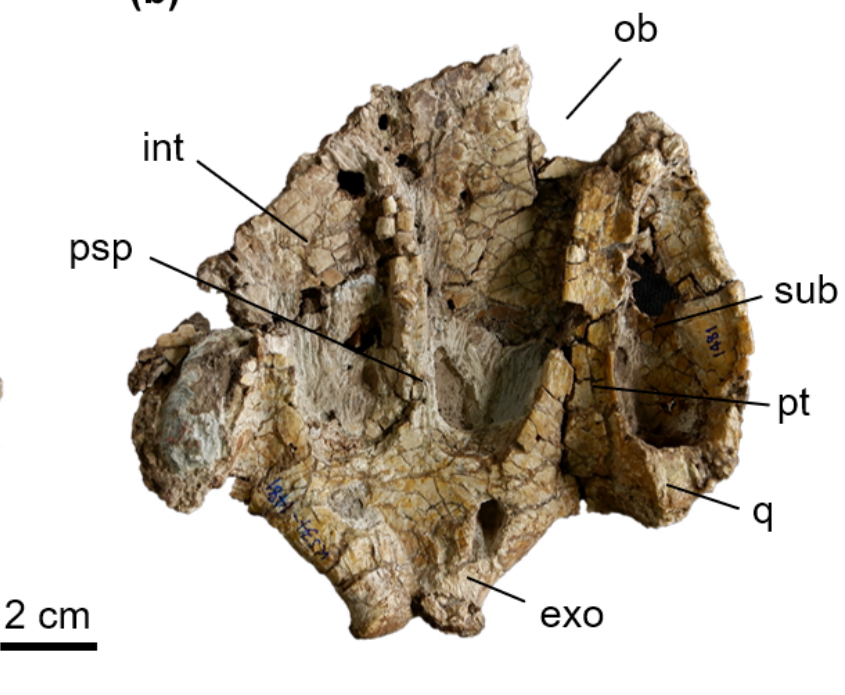

(d)

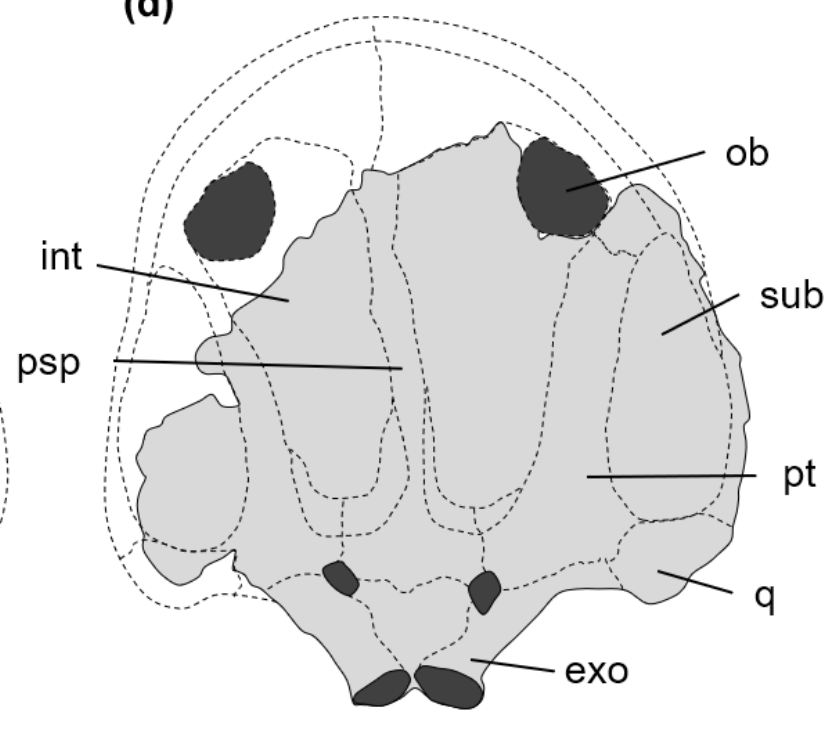

(e)

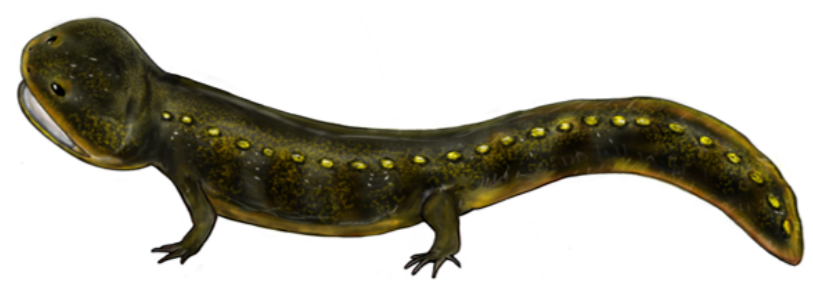

Figure 6. Posterior part skull of Brachyopidae indet. (KS34-1481) from Phu Noi locality, in dorsal (a) and palatal views (b). Reconstruction outline of KS34-1481 (estimate reconstruction outline of the anterior part based on Sinobrachyops placenticephalus Dong, 1985) in dorsal (c) and palatal views (d). Reconstruction of Thai Brachyopidae (e) is not to scale (drawn by Sita Manitkoon). Abbreviations: oc, occipital condyles; exo, exoccipital; int, interpalatal vacuities; ob, orbit; p, parietal; pp, postparietal; pt, pterygoid; psp, parasphenoid; st, supratemporal; sub, subtemporal fossa; t, tabular; q, quadrate. 
connection between the North China block, South China block, Indochina block and Laurussia during the Mesozoic era (Permo-Triassic boundary) (Ingavat and Janvier 1981; Bercovici et al., 2012; Arbez et al., 2018; Olivier et al., 2019).

In the Jurassic sequence of Thailand, the previous records of Mesozoic amphibians were limited to intercentra remains (TF 3328, TF 3329, TF 3144), which share common characters with Brachyopoidea intercentra (Shishkin, 1991). Remains of Brachyopoidea have been discovered in Australia (Damiani and Warren, 1996; Cosgriff, 1973; Warren and Hutchinson, 1983; Warren et al., 2011), Africa (Chernin, 1977; Warren and Dammiani, 1999; Damiani and Rubidge, 2003; Damiani and Kitching, 2003), South America (Marsicano, 1993, 1999, 2005; Ruta and Bolt, 2008; Dias-daSilva et al., 2012), Russia (Shishkin, 1967), Antarctica (Cosgriff and Hammer, 1984), India (Sengupta, 1995), Mongolia (Shishkin, 1991), and China (Dong, 1985). The new Brachyopidae skull (KS34-1481) from the Phu Noi locality, briefly described in this study, resembles that of Sinobrachyops placenticephalus Dong, 1985 from China, suggesting that these forms are related. This would indicate a biogeographical link between the Sibumasu block and the Chinese sediments. Moreover, the wide distribution of temnospondyls in Asian continental blocks during the Jurassic supports the view that the Sibumasu block and Indochina block were already in contact (Buffetaut et al., 1994a; Buffetaut and Suteethorn, 1998).

Amphibian fossils from the Early Cretaceous of northeastern Thailand are described and related to anurans, although these specimens are too fragmentary to be more precisely identified. In the Cretaceous, Asian anurans have been discovered in Kazakhstan (Skutschas and Kolchanov, 2017), Mongolia (Gao and Chen, 2017), India (Prasad and Rage, 2004), Japan (Evans and Manabe, 1998), China (Wang et al., 2000; Yuan, 2004; Dong et al., 2013), and Myanmar (Xing et al., 2018). Thus, the discovery of this taxon suggests that during the Early Cretaceous, anurans were already present in Thailand.

\section{Conclusions}

The non-marine Mesozoic sedimentary rocks from Thailand were formed in the Indochina and Sibumasu blocks. These blocks have yielded at least four taxa of amphibians, including three taxa of temnospondyls (Cyclotosaurus cf. posthumus, Plagiosauridae, and Brachyopidae) and one taxon of anuran from four formations (Huai Hin Lat Formation, Khlong Min Formation, Phu Kradung Formation, and Sao Khua Formation) with ranges from the Late Triassic to Early Cretaceous. The Thai amphibian fossils show the most diverse Mesozoic amphibian record in Southeast Asia, and this agrees with the hypothesis of a large physical connection between the Indochina block and Laurussia during the Mesozoic era.
Data availability. All material included in this paper is deposited in the Palaeontological Research and Education Centre, Mahasarakham University and in the collection of the Department of Mineral Resources (Thailand).

Author contributions. TN and SM produced the images. TN and KL drafted the manuscript. All authors prepared the paper and contributed to the editing.

Competing interests. The authors declare that they have no conflict of interest.

Acknowledgements. We would like to thank Varavudh Suteethorn, Eric Buffetaut, Phornphen Chanthasit, Paladej Srisuk, and Bouziane Khalloufi for their useful suggestions and comments. We are grateful to the staff of the Palaeontological Research and Education Centre of Mahasarakham University and the Sirindhorn Museum, who took part in our fieldwork and helped during visits to the museums. Thanit Nosrirach was financially supported by the Faculty of Science, Mahasarakham University (grant year 2020), Science Achievement Scholarship of Thailand (SAST), and Komsorn Lauprasert was supported by the Palaeontological Research and Education Centre, Mahasarakham University (grant year 2020).

Financial support. This research has been supported by the Palaeontological Research and Education Centre, Mahasarakham University (grant no. PRC003/2563).

Review statement. This paper was edited by Florian Witzmann and reviewed by J. S. Steyer and one anonymous referee.

\section{References}

Abel, O.: Die stämme der Wirbeltiere, W. de Gruyter, 1919 (in German).

Arbez, T., Sidor, C. A., and Steyer, J. S.: Laosuchus naga gen. et sp. nov., a new chroniosuchian from South-East Asia (Laos) with internal structures revealed by micro-CT scan and discussion of its palaeobiology, J. Syst. Palaeontol., 17, 1165-1182, 2018.

Antczak, M. and Bodzioch, A.: Ornamentation of dermal bones of Metoposaurus krasiejowensis and its ecological implications, PeerJ, 6, e5267, https://doi.org/10.7717/peerj.5267, 2018.

Averianov, A. O., Martin, T., Skutschas, P. P., Rezvyi, A. S., and Bakirov, A. A.: Amphibians from the Middle Jurassic Balabansai Svita in the Fergana Depression, Kyrgyzstan (Central Asia), Palaeontol., 51, 471-485, 2008.

Bercovici, A., Bourquin, S., Broutin, J., Steyer, J. S., Battail, B., Véran, M., Vacant, R., Khenthavong, B., and Vongphamany, S.: Permian continental paleoenvironments in Southeastern Asia: new insights from the Luang Prabang Basin (Laos), J. Asian Earth Sci., 60, 197-211, 2012. 
Branson, E. B. and Mehl, M. G.: Triassic Amphibians from the Rocky Mountain Region, University of Missouri Studies 4, 155239, 1929.

Brusatte, S. L., Butler, R. J., Mateus, O., and Steyer, J. S.: A new species of Metoposaurus from the Late Triassic of Portugal and comments on the systematics and biogeography of metoposaurid temnospondyls, J. Vertebr. Paleontology, 35, e912988, https://doi.org/10.1080/02724634.2014.912988, 2015.

Buffetaut, E. and Ingavat, R.: A new crocodilian from the Jurassic of Thailand, Sunosuchus thailandicus n. sp. (Mesosuchia, Goniopholididae), and the palaeogeographical history of South-East Asia in the Mesozoic, Geobios, 13, 879-889, 1980.

Buffetaut, E. and Ingavat, R.: Phytosaur remains (Reptilia, Thecodontia) from the Upper Triassic of North-Eastern Thailand, Geobios, 15, 7-17, 1982.

Buffetaut, E. and Suteethorn, V.: The biogeographical significance of the Mesozoic vertebrates from Thailand, Biogeography and Geological Evolution of SE Asia, 2, 83-90, 1998.

Buffetaut, E. and Suteethorn, V.: The dinosaur fauna of the Sao Khua Formation of Thailand and the beginning of the Cretaceous radiation of dinosaurs in Asia, Palaeogeogr. Palaeocl., 150, 1323, 1999.

Buffetaut, E., Tong, H., and Suteethorn, V.: First post-Triassic labyrinthodont amphibian in South East Asia: a temnospondyl intercentrum from the Jurassic of Thailand, Geol. Palaont. Mh., 7, 385-390, 1994a.

Buffetaut, E., Tong, H., and Suteethorn, V.: Jurassic vertebrates from the southern peninsula of Thailand and their implications, A preliminary report, in: Proceedings of the International Symposium on: Stratigraphic Correlation of Southeast Asia, Thailand, 15-20 November 1994, 253-256, 1994b.

Buffetaut, E., Raksaskulwong, L., Suteethorn, V., and Tong, H.: First post-Triassic temnospondyl amphibians from the Shan-Thai block: intercentra from the Jurassic of peninsular Thailand, Geol. Mag., 131, 837-839, 1994c.

Buffetaut, E., Suteethorn, S., Suteethorn, V., Deesri, U., and Tong, H.: Preliminary note on a small ornithopod dinosaur from the Phu Kradung Formation (terminal Jurassic-basal Cretaceous) of Phu Noi, North-eastern Thailand, J. Sci. Technol. Mahasarakham Univ., 33, 344-347, 2014.

Case, E. C.: New reptiles and stegocephalians from the Upper Triassic of western Texas (No. 321), Carnegie Institution of Washington, 1922.

Cavin, L. and Suteethorn, V.: A new semionotiform (Actinopterygii, Neopterygii) from Upper Jurassic-Lower Cretaceous deposits of North-East Thailand, with comments on the relationships of semionotiforms, Palaeontology, 49, 339-353, 2006.

Cavin, L., Deesri, U., and Chanthasit, P.: A new lungfish from the Jurassic of Thailand, J. Vertebr. Paleontol., 40, e1791895, https://doi.org/10.1080/02724634.2020.1791895, 2020.

Cavin, L., Suteethorn, V., Bufeetaut, E., Lauprasert, K., Le Loeuff, J., Lutat, P., Richter, U., and Tong, H.: Palaeobiogeographical Affinities of Fish from Phu Nam Jun, Late Jurassic-Early Cretaceous of North-Eastern Thailand, in: 1st International Conference on Palaeontology of Southeast Asia, Thailand, 27-30 October 2003, 22, 217-227, 2003.

Cavin, L., Deesri, U., and Suteethorn, V.: The Jurassic and Cretaceous bony fish record (Actinopterygii, Dipnoi) from Thailand, Geol. Soc. Spec. Publ., 315, 125-139, 2009.
Chakravorti, S. and Sengupta, D. P.: Taxonomy, morphometry and morphospace of cranial bones of Panthasaurus gen. nov. maleriensis from the Late Triassic of India, J. Iber. Geol., 45, 317340, 2019.

Chanthasit, P., Suteethorn, S., Manitkoon, S., Nonsrirach, T., and Suteethorn, V.: Biodiversity of the Late Jurassic/Early Cretaceous Phu Noi, Phu Kradung Formation, Kalasin, Thailand, in: The International Symposium and Workshop "Advancing Paleontological Research and Specimen Conservation in Southeast Asia, 17-19 December 2019, Bangkok, Thailand, 14-16, 2019.

Chernin, S.: A new brachyopid, Batrachosuchus concordi sp. nov. from the Upper Luangwa Valley, Zambia with a redescription of Batrachosuchus browni Broom, 1903, Palaeont. Afr., 20, 87109, 1977.

Chowdhury, T. R.: A new metoposaurid amphibian from the Upper Triassic Maleri Formation of Central India, Philos. T. Roy. Soc. B, 250, 1-52, 1965.

Cosgriff, J. W.: Notobrachyops picketti, a brachyopid from the Ashfield Shale, Wiannamatta Group, New South Wales, J. Paleontol., 47, 1094-1101, 1973.

Cosgriff, J. W. and Hammer, W. R.: New material of labyrinthodont amphibians from the Lower Triassic Fremouw Formation of Antarctica, J. Vertebr. Paleontol., 4, 47-56, 1984.

Cuny, G., Suteethorn, V., and Kamha, S.: A review of the hybodont sharks from the Mesozoic of Thailand, Geotechnology and Mineral Resources of Indochina, Khon Kaen University, 588-593, 2005.

Cuny, G., Suteethorn, V., Kamha, S., Lauprasert, K., Srisuk, P., and Buffetaut, E.: The Mesozoic fossil record of sharks in Thailand, Geothai'07 International Conference on Geology of Thailand: Towards Sustainable Development and Sufficiency Economy, 21-22 November 2007, Bangkok, Thailand, 349-345, 2007.

Cuny, G., Liard, R., Deesri, U., Liard, T., Khamha, S., and Suteethorn, V.: Shark faunas from the Late Jurassic-Early Cretaceous of Northeastern Thailand, Palaontol. Z., 88, 309-328, 2014.

Dahoumane, A., Nedjari, A., Aït-Ouali, R., Taquet, P., Vacant, R., and Steyer, J. S.: A new mastodonsauroid temnospondyl from the Triassic of Algeria: implications for the biostratigraphy and palaeoenvironments of the Zarzaitine Series, Northern Sahara, C. R. Palevol., 15, 918-926, 2016.

Damiani, R. J.: Giant temnospondyl amphibians from the Early to Middle Triassic Narrabeen Group of the Sydney Basin, New South Wales, Australia, Alcheringa, 23, 87-109, 1999.

Damiani, R. J.: A systematic revision and phylogenetic analysis of Triassic mastodonsauroids (Temnospondyli: Stereospondyli), Zool. J. Linn. Soc.-Lond., 133, 379-482, 2001.

Damiani, R. J. and Rubidge, B. S.: A review of the South African temnospondyl amphibian record, Palaeont. Afr., 39, 21-36, 2003.

Damiani, R. J. and Kitching, J. W.: A new brachyopid temnospondyl from the Cynognathus Assemblage Zone, Upper Beaufort Group, South Africa, J. Vertebr. Paleontol., 23, 67-78, 2003.

Damiani, R. J. and Warren, A.: A new look at members of the Superfamily Brachyopoidea (Amphibia, Temnospondyli) from the Early Triassic of Queensland and a preliminary analysis of brachyopoid relationships, Alcheringa, 20, 277-300, 1996. 
Deesri, U., Lauprasert, K., Varavudh, S., Wongko, K., and Cavin, L.: A new species of the ginglymodian fish Isanichthys (Actinopterygii, Holostei) from the Late Jurassic Phu Kradung Formation, Northeastern Thailand, Acta Palaeontol. Pol., 59, 313-331, 2014.

Department of Mineral Resources: Geology of Thailand, Department of Mineral Resources, Ministry of Natural Resources and Environment, Bangkok, Thailand, 508, 2014.

Dias-Da-Silva, S., Sengupta, D. P., Cabreira, S. F., and Da Silva, L. R.: The presence of Compsocerops (Brachyopoidea: Chigutisauridae) (Late Triassic) in southern Brazil with comments on chigutisaurid palaeobiogeography, Palaeontology, 55, 163-172, 2012.

Dias-da-Silva, S. and Dias, E. V.: A comprehensive survey of Triassic stereospondyls from southern Brazil with comments on their overall significance, Bull. N. Mex. Mus. Nat. Hist. Sci., 61, 1-93, 2013.

Dong, Z.: The Dashanpu Dinosaur Fauna of Zigong Sichuan short report Labyrinthodont Amphibia, Vertebrat. Palasiatic., 23, 301305, 1985.

Dong, L., Roček, Z., Wang, Y., and Jones, M. E. H.: Anurans from the Lower Cretaceous Jehol Group of Western Liaoning, China, Plos One, 8, e69723, https://doi.org/10.1371/journal.pone.0069723, 2013.

Dutuit, J. M.: Description de quelques fragments osseux provenant de la région de Folakara (Trias supérieur malgache), Bulletin de Museum Nationale d'Histoire naturelle, Paris, Series III, 516, 79-89, 1978 (in French).

Dzik, J. and Sulej, T.: A review of the early Late Triassic Krasiejów biota from Silesia, Poland, Phytopatologia Polonica, 64, 3-27, 2007.

Eltink, E., Da-Rosa, Átila, A. S., and Dias-da-Silva, S.: A capitosauroid from the Lower Triassic of South America (Sanga do Cabral Supersequence: Paraná Basin), its phylogenetic relationships and biostratigraphic implications, Hist. Biol., 29, 863-874, 2017.

Evans, S. E. and Manabe, M.: Early Cretaceous frog remains from the Okurodani Formation, Tetori Group, Japan, Paleontol. Res., 2, 275-278, 1998.

Fischer von Waldheim, G.: Zoognosia tabulis synopticis illustrata: in usum praelectionorum Academiae Imperialis MedicoChirurgicae Mosquensis edita, 3rd Edn., Nicolai Sergeidis Vsevolozsky, Moscow, 1813.

Fortuny, J., Galobart, À., and De Santisteban, C.: A new Capitosaur from the Middle Triassic of Spain and the relationships within the Capitosauria, Acta Palaeontol. Pol., 56, 553-566, 2011.

Fortuny, J., Arbez, T., Mujal, E., and Steyer, J. S.: Reappraisal of "Metoposaurus hoffmani" Dutuit, 1978, and description of new temnospondyl specimens from the Middle-Late Triassic of Madagascar (Morondava Basin), J. Vertebr. Paleontol., 39, e1576701, https://doi.org/10.1080/02724634.2019.1576701, 2019.

Fraas, E.: Die Labyrinthodonten der Schwabischen Trias, Palaeontographica, 36, 1-158, 1889.

Fraas, E.: Neue Labyrinthodonten aus der Schwabischen Trias, Palaeontographica, 60, 275-294, 1913.

Gao, K. Q. and Chen, J.: A new crown-group frog (Amphibia: Anura) from the Early Cretaceous of Northeastern Inner Mongolia, China, American Museum Novitates, 2017, 1-39, 2017.
Girard, V., Saint Martin, S., Buffetaut, E., Saint Martin, J. P., Néraudeau, D., Peyrot, D., Roghi, G., Ragazzi, E., and Suteethorn, V.: Thai amber: insights into early diatom history?, Earth Sci. Bull., 191, 1-13, https://doi.org/10.1051/bsgf/2020028, 2020.

Havlik, P., Aiglstorfer, M., Atfy, H. E., and Uhl, D.: A peculiar bonebed from the Norian Stubensandstein (Löwenstein Formation, Late Triassic) of southern Germany and its palaeoenvironmental interpretation, Neues Jahrb. Geol. P.-A., 269, 321-337, 2013.

Ingavat, R. and Janvier, P.: Cyclotosaurus cf. posthumus Fraas (Capitosauridae, Stereospondyli) from the Huai Hin Lat Formation (Upper Triassic), northeastern Thailand, with a note on capitosaurid biogeography, Geobios, 14, 711-725, 1981.

Jenkins Jr, F. A., Shubin, N. H., Gatesy, S. M., and Warren, A.: Gerrothorax pulcherrimus from the Upper Triassic Fleming Fjord Formation of East Greenland and a reassessment of head lifting in temnospondyl feeding, J. Vertebr. Paleontol., 28, 935-950, 2008.

Kobayashi, T.: Upper Triassic estheriids in Thailand and the conchostracan development in Asia in the Mesozoic Era, Geol. Palaeontol. Southeast Asia, 16, 57-90, 1975.

Konietzko-Meier, D., Danto, M., and Gądek, K.: The microstructural variability of the intercentra among temnospondyl amphibians, Biol. J. Linn. Soc., 112, 747-764, 2014.

Laojumpon, C., Matkhammee, T., Wathanapitaksakul, A., Suteethorn, V., Suteethorn, S., Lauprasert, K., Srisuk, S., Loeuff, J. L. E.: Preliminary report on coprolites from the Late Triassic of Thailand, Vertebrate Coprolites, Bull. N. Mex. Mus. Nat. Hist. Sci., 57, 207-213, 2012.

Laojumpon, C., Deesri, U., Khamha, S., Wattanapituksakul, A., Lauprasert, K., Suteethorn, S., and Suteethorn, V.: New vertebrate-bearing localities in the Triassic of Thailand, J. Sci. Technol. MSU, 4, 335-343, 2014.

Lopez-Arbarello, A.: Revision of Semionotus bergeri Agassiz, 1833 (Upper Triassic, Germany), with comments on the taxonomic status of Semionotus (Actinopterygii, Semionotiformes), Paläontol. Z., 82, 40-54, 2008.

Lei, Z.: The discovery and significance of the Late Jurassic sporopollen assemblage in peninsular Thailand, Biostratigraphy of Mainland Southeast Asia: Facies and Paleontology, Department of Geological Sciences, Chiang Mai University, 1993.

Liu, J.: Yuanansuchus maopingchangensis sp. nov., the second capitosauroid temnospondyl from the Middle Triassic Badong Formation of Yuanan, Hubei, China, PeerJ, 4, e1903, https://doi.org/10.7717/peerj.1903, 2016.

Liu, J. and Wang, Y.: The first complete mastodonsauroid skull from the Triassic of China: Yuanansuchus laticeps gen. et sp. nov., J. Vertebr. Paleontol., 25, 725-728, 2005.

Lucas, S. G., Rinehart, L. F., Krainer, K., Spielmann, J. A., and Heckert, A. B.: Taphonomy of the Lamy amphibian quarry: a Late Triassic bonebed in New Mexico, USA, Palaeogeogr. Palaeocl., 298, 388-398, 2010.

Lydekker, R.: The Reptilia and Amphibia of the Maleri and Denwa Groups, Palaeontologia Indica (Ser. IV. Indian pre-Tertiary Vertebrata) 1, 30-38, 1885.

Martin, M.: The actinopterygian scales and teeth (PISCES) from the continental; Upper Triassic of Thailand, their paleogeographical 
significance, Mémoires de la Société géologique de France 1924, 147, 101-105, 1984.

Martin, M. and Ingavat, R.: First record of an Upper Triassic Ceratodontid (Dipnoi, Ceratodontiformes) in Thailand and its paleogeographical significance, Geobios, 15, 111-114, 1982.

Martin, J. E., Suteethorn, S., Lauprasert, K., Tong, H., Buffetaut, E., Liard, R., Salaviale, C., Deesri, U., Suteethorn, V., and Claude, J.: A new freshwater teleosaurid from the Jurassic of northeastern Thailand, J. Vertebr. Paleontol., 38, e1549059, https://doi.org/10.1080/02724634.2018.1549059, 2018.

Marsicano, C. A.: Postcranial skeleton of a brachyopoid (Amphibia, Temnospondyli) from the Triassic of Mendoza (Argentina), Alcheringa, 17, 185-197, 1993.

Marsicano, C. A.: Chigutisaurid amphibians from the Upper Triassic of Argentina and their phylogenetic relationships, Palaeontology, 42, 545-565, 1999.

Marsicano, C. A.: A new temnospondyl record from the Upper Triassic of Argentina, Ameghiniana, 42, 501-504, 2005.

Maryanska, T. and Shishkin, M. A.: New cyclotosaurid (Amphibia: Temnospondyli) from the Middle Triassic of Poland and some problems of interrelationships of capitosauroids, Prace Muzeum Ziemi, 43, 53-83, 1996.

Marzola, M., Mateus, O., Shubin, N. H., and Clemmensen, L. B.: Cyclotosaurus naraserluki, sp. nov., a new Late Triassic cyclotosaurid (Amphibia, Temnospondyli) from the Fleming Fjord Formation of the Jameson Land Basin (East Greenland), J. Vertebr. Paleontol., 37, e1303501, https://doi.org/10.1080/02724634.2017.1303501, 2017.

Meesook, A.: Cretaceous environments of northeastern Thailand, in: Developments in Palaeontology and Stratigraphy, Elsevier, 17, 207-223, https://doi.org/10.1016/S0920-5446(00)80034-5, 2000.

Meesook, A., Suteethorn, V., and Sattayarak, N.: Cretaceous system of the Khorat Plateau, northern Thailand, in: The Cretaceous System in East and South Asia, Kyushu University, Fukuoka, 25-34, 1995.

Metcalfe, I.: Gondwanaland dispersion, Asian accretion and evolution of eastern Tethys, Aust. J. Earth Sci., 43, 605-623, 1996.

Milner, A. R. and Schoch, R. R.: The latest metoposaurid amphibians from Europe, Neues Jahrb. Geol. P.-A., 232, 231-252, 2004.

Milner, A. R., Fraser, N. C., and Sues, H. D. (Eds.): Late Triassic and Jurassic amphibians: fossil record and phylogeny, in: The shadow of the dinosaurs: Early Mesozoic Tetrapods, Cambridge University Press, USA, 221 pp., 1994.

Moser, M. and Schoch, R.: Revision of the type material and nomenclature of Mastodonsaurus giganteus (Jaeger) (Temnospondyli) from the Middle Triassic of Germany, Palaeontology, 50, 1245-1266, 2007.

Mukherjee, R. N. and Sengupta, D. P.: New capitosaurid amphibians from the Triassic Denwa Formation of the Satpura Gondwana basin, central India, Alcheringa, 22, 317-327, 1998.

Nakajima, Y. and Schoch, R. R.: The first temnospondyl amphibian from Japan, J. Vertebr. Paleontol., 31, 1154-1157, 2011.

Novikov, I. V. and Ilyina, N. V.: Continental Triassic biostratigraphy of the Bolshaya Synya and Korotaikha depressions, North CisUrals, Russia: tetrapod and palynological data, Palaeobotanist, 44, 12-138, 1995.

Olivier, C., Battail, B., Bourquin, S., Rossignol, C., Steyer, J. S., and Jalil, N. E.: New dicynodonts (Therapsida, Anomod- ontia) from near the Permo-Triassic boundary of Laos: implications for dicynodont survivorship across the PermoTriassic mass extinction and the paleobiogeography of Southeast Asian blocks, J. Vertebr. Paleontol., 39, e1584745, https://doi.org/10.1080/02724634.2019.1584745, 2019.

Prasad, G. V. and Rage, J. C.: Fossil frogs (Amphibia: Anura) from the Upper Cretaceous Intertrappean Beds of Naskal, Andhra Pradesh, India, Rev. Paleobiol., 23, 99-116, 2004.

Peecook, B. R., Steyer, J. S., Tabor, N. J., and Smith, R. M.: Updated geology and vertebrate paleontology of the Triassic Ntawere Formation of northeastern Zambia, with special emphasis on the archosauromorphs, J. Vertebr. Paleontol., 37, 8-38, 2017.

Racey, A.: Mesozoic red bed sequences from SE Asia and the significance of the Khorat Group of NE Thailand, Geol. Soc. Spec. Pub., 315, 41-67, 2009.

Racey, A., Goodall, J. G. S., Love, M. A., Polachan, S., and Jones, P. D.: New age data for the Mesozoic Khorat Group of northeast Thailand, In: Proceedings of the International Symposium on Stratigraphic Correlation of Southeast Asia, Department of Mineral Resources, 15-20 November 1994, Bangkok, Thailand, 245-252, 1994.

Racey, A., Love, M. A., Canham, A. C., Goodall, J. G. S., Polachan, S., and Jones, P. D.: Stratigraphy and reservoir potential of the Mesozoic Khorat Group, NE Thailand: Part 1: stratigraphy and sedimentary evolution, J. Petrol. Geol., 19, 5-39, 1996.

Ruta, M. and Bolt, J. R.: The brachyopoid Hadrokkosaurus bradyi from the early Middle Triassic of Arizona, and a phylogenetic analysis of lower jaw characters in temnospondyl amphibians, Acta Palaeontol, Pol,, 53, 579-592, 2008.

Schoch, R. R.: Comparative Osteology of Mastodonsaurus Giganteus (Jaeger, 1828) from the Middle Triassic (Lettenkeuper: Longobardian) of Germany (Baden-Württemberg, Bayern, Thüringen), Staatl. Museum für Naturkunde, tuttgarter Beiträge zur Naturkunde Serie B (Geologie and Paläontologie), 278, 175 pp., 1999.

Schoch, R. R.: The status and osteology of two new cyclotosaurid amphibians from the Upper Moenkopi Formation of Arizona (Amphibia: Temnospondyli; Middle Triassic), Neues Jahrb. Geol. P.-A., 216, 387-411, 2000.

Schoch, R. R.: Amphibian evolution: the life of early land vertebrates, edited by: Benton, M. J., John Wiley \& Sons, United Kingdom, 264 pp., 2014.

Schoch, R. R. and Milner, A. R.: Handbuch der Paläoherpetologie: Stereospondyli, Tail 3, Verlag Dr. Friedrich Pfeil - München, Germany, 203 pp., 2000.

Sengupta, D. P.: Chigutisaurid temnospondyls from the late Triassic of India and review of the family Chigutisauridae, Palaeontology, 38, 313-339, 1995.

Sengupta, D. P.: Indian metoposaurid amphibians revised, Paleontol. Res., 6, 41-65, 2002.

Shishkin, M. A.: Suborder Stereospondyli, in: Osnovy Paleontologii, Amphibia, Reptila, edited by: Orlov, Y. A., Aves, Moscow, Nauka, 83-122, 1964 (in Russian).

Shishkin, M. A.: A brachyopid labyrinthodont from the Triassic of the Russian Platform, Int. Geol. Rev., 9, 310-322, 1967.

Shishkin, M. A.: On the Morphological Evolution of Plagiosaurs (Amphibia: Labyrinthodontia), in: Studies in Herpetology, edited by: Rocek, Z., Charles University, Prague, 41-44, 1986. 
Shishkin, M. A.: A late Jurassic labyrinthodont from Mongolia, Paleontol. J., 1, 78-91, 1991.

Shishkin, M. A., Rubidge, B., Hancox, J., and Welman, J.: Re-evaluation of Kestrosaurus Haughton, a capitosaurid temnospondyl amphibian from the Upper Beaufort group of South Africa, Russ. J. Herpetol., 11, 121-138, 2004.

Skutschas, P. P. and Kolchanov, V. V.: Anurans (Amphibia: Anura) from the Upper Cretaceous (Santonian-lower Campanian) Bostobe Formation of Northeastern Aral Sea Region, Kazakhstan, Palaeoworld, 26, 202-208, 2017.

Srisuk, P.: First evidence of anura amphibians from the Sao Khua Fomtion (Ealy Cretaeous) of northeastern Thailand, Bulletin of the Srisuk's House Museum, 3, 40-45, 2002.

Srisuk, P.: Additional records of anuran amphibian from the early Cretaceous (Sao Khua Formation) of northeastern Thailand, Bulletin of the Srisuk's House Museum, 6, 1-6, 2005.

Sulej, T.: Species discrimination of the Late Triassic temnospondyl amphibian Metoposaurus diagnosticus Comparison of European and North American metoposaurids, Acta Palaeontol. Pol., 47, 535-546, 2002.

Sulej, T.: Osteology, variability, and evolution of Metoposaurus, a temnospondyl from the Late Triassic of Poland, Palaeontol. Pol., 64, 29-139, 2007.

Sulej, T. and Majer, D.: The temnospondyl amphibian Cyclotosaurus from the Upper Triassic of Poland, Palaeontology, 48, 157-170, 2005.

Sulej, T. and Niedźwiedzki, G.: A new large capitosaurid temnospondyl amphibian from the Early Triassic of Poland, Acta Palaeontol. Pol., 58, 65-75, 2013.

Suteethorn, V., Janvier, P., and Morales, M.: Evidence for a Plagiosaurid amphibian in the Upper Triassic Huai Hin Lat Formation of Thailand, J. Southeast Asian Earth Sci., 2, 185-187, 1988.

Tong, H., Buffetaut, E., and Suteethorn, V.: Middle Jurassic turtles from southern Thailand, Geol. Mag., 139, 687-697, 2002.

Tong, H., Buffetaut, E., and Suteethorn, V.: Mesozoic turtles of Thailand, in: 1st International Conference on Palaeontology of Southeast Asia, 27-30 October 2003, Mahasarakham University, Thailand, 41-48, 2003.

Tong, H., Claude, J., Suteethorn, V., Naksri, W., and Buffetaut, E.: Turtle assemblages of the Khorat Group (Late Jurassic-Early Cretaceous) of NE Thailand and their palaeobiogeographical significance, Geol. Soc. Spec. Pub., 315, 141-152, 2009.

Tong, H., Naksri, W., Buffetaut, E., Suteethorn, V., Suteethorn, S., Deesri, U., Sila, S., Chanthasit, P., and Claude, J.: A new primitive eucryptodiran turtle from the Upper Jurassic Phu Kradung Formation of the Khorat Plateau, NE Thailand, Geol. Mag., 152, $166-175,2015$

Tong, H., Naksri, W., Buffetaut, E., Suteethorn, S., Suteethorn, V., Chantasit, P., and Claude, J.: Kalasinemys, a new xinjiangchelyid turtle from the Late Jurassic of NE Thailand, Geol. Mag., 156, 1645-1656, 2019.
Vitt, L. J. and Caldwell, J. P.: Herpetology: an introductory biology of amphibians and reptiles, fourth edition, Academic press, USA, 757 pp., 2014.

von Meyer, H.: Letter on Mesozoic amphibians and reptiles, Neues Jahrb. Mineral., Geol. Palaontol., 1842, 301-304, 1842.

Wang, Y., Gao, K. Q., and Xu, X.: Early evolution of discoglossid frogs: new evidence from the Mesozoic of China, Naturwissenschaften, 87, 417-420, 2000.

Warren, A.: Triassic amphibians and reptiles of Australia in relation to Gondwanaland, Aust. Nat. Hist., 17, 279-283, 1972.

Warren, A. and Damiani, R.: Stereospondyl amphibians from the Elliot Formation of South Africa, Palaeont. Afr., 35, 45-54, 1999.

Warren, A. and Hutchinson, M. N.: The last labyrinthodont? A new brachyopoid (Amphibia, Temnospondyli) from the Early Jurassic Evergreen Formation of Queensland, Australia, Philos. T. Roy. Soc. B, 303, 1-62, 1983.

Warren, A. and Snell, N.: The postcranial skeleton of Mesozoic temnospondyl amphibians: A review, Alcheringa, 15, 43-64, 1991.

Warren, A. and Marsicano, C.: Revision of the Brachyopidae (Temnospondyli) from the Triassic of the Sydney, Carnarvon and Tasmania basins, Australia, Alcheringa, 22, 329-342, 1998.

Warren, A. and Marsicano, C.: A phylogeny of the Brachyopoidea (Temnospondyli, Stereospondyli), J. Vertebr. Paleontol., 20, 462-483, 2000.

Warren, A., Rich, T. H., and Vickers-Rich, P.: The last labyrinthodonts, Palaeontographica Abteilung Stuttgart, 247, 10-24, 1997.

Warren, A., Rozefelds, A. C., and Bull, S.: Tupilakosaur-like vertebrae in Bothriceps australis, an Australian brachyopid stereospondyli, J. Vertebr. Paleontol., 31, 738-753, 2011.

Witzmann, F. and Gassner, T.: Metoposaurid and mastodonsaurid stereospondyls from the Triassic - Jurassic boundary of Portugal, Alcheringa, 32, 37-51, 2008.

Xing, L., Stanley, E. L., Bai, M., and Blackburn, D. C.: The earliest direct evidence of frogs in wet tropical forests from Cretaceous Burmese amber, Sci. Rep.-UK, 8, 8770, https://doi.org/10.1038/s41598-018-26848-w, 2018.

Yuan, W.: Taxonomy and stratigraphy of late Mesozoic anurans and urodeles from China, Acta Geol. Sin.-Engl., 78, 1169-1178, 2004.

Zeigler, K. E., Lucas, S. G., and Heckert, A. B.: Taphonomy of the Late Triassic Lamy amphibian quarry (Garita Creek Formation: Chinle Group), central New Mexico, N. Mex. Mus. Nat. Hist. Sci. Bull., 21, 279-283, 2002.

Zittel, K. V.: Amphibia, in: Handbuch der Paläontologie, I Abteilung, Palaeozoologie, Oldenbourg, Munich, 337-437, 1888 . 